\title{
Lactation and Sample Test-Day Multi-trait animal model for genetic evaluation of somatic cell scores in Hungarian HoIstein-Friesian crossbreeds
}

\begin{abstract}
Summary
Genetic and phenotypic correlations were estimated for means of $\log _{2}$ SCC (somatic cell scores: SCS) with milk production traits using complete lactation and sample test-day data sets. Data of SCS and milk production traits for six genetic groups of Holstein-Friesian (HF), Hungarian Native Breed (NHB) and four of theit crossbreeds were used. Multi trait animal model was used for the estimation of all genetic and phenotypic (co)-variances. All estimates of correlations either genetic $\left(R_{g}\right)$ or phenotypic $\left(R_{p}\right)$ between SCS and milk production traits were mostly negative except with protein percentage, Lactation $(\mathrm{L})$ estimates of $R_{\mathrm{g}}$ between $\mathrm{SCS}$ and total milk yield $(\mathrm{MY})$, fat $\left(\mathrm{F}_{\mathrm{L}}\right)$, protein $\left(\mathrm{P}_{\mathrm{L}}\right)$ and lactose $\left(\mathrm{Lc}_{1}\right)$ percentages were $-.11 \pm .10,-.12 \pm .04, .09 \pm .03$, and $-.18 \pm .09$. respectively and the corresponding sample test-day estimates (STD) were $-.13 \pm .07,-.13 \pm .08, .11 \pm .04,-11 \pm .08$, respectively. $\mathrm{L}$ and STD $R_{p}$ estimates of SCS with MY and protein were higher than the corresponding $R_{\mathrm{g}}$. L$R \mathrm{~g}$ of SCS with MY and protein and L- $R_{\mathrm{p}}$ with fat and lactose were increased with parity $R_{\mathrm{g}}$ either $\mathrm{L}$ or STD with fat decreased with the parity. The highest estimates of L- $R_{g}$ of SCS with MY were negative for HF in the $2^{\text {nd }}$ and the $3^{\text {rd }}$ parity and were ranged from -0.13 to $-0.17 . R_{g}$ of SCS STD with daily milk yield (DY) across parity in different genetic groups were higher than the corresponding with MY. All correlations of SCS with protein were positive. $L-R_{g}$ ranged from .17 to, 22 for $\mathrm{HF}$ vs. .01 to .04 for $\mathrm{NHB}$. While $\mathrm{L}-R_{p}$ ranged from .06 to, 15 for HF $v_{5} .04$ to .11 for NHB. fi could be concluded that, trend of the relationship for SCS with milk production may had some change in crossbred than purebred according to percentage of crossing.
\end{abstract}

Key Words: somatic cell, correlations, milk, Hungarian-Holstein Friesian, HF-crossbreeds

\section{Zusammenfassung}

Titei der Arbeit: Mehrmerkmalsmodell zur Bewertung von Zusammenhängen von somatischer Zellzahl, Laktationsleistung und Testtagsproben bei Ungarischen Holstein-Friesen Kreuzungskilhen

Es werden genetische und phănotypische Beziehungen zwischen der somatischen Zellzahl (SCS) und Milchmenge bzw, -inhaltsstoffen bei Gesamtlaktationsleistung und Testlagsdaten geschätzt. Einbezogen wurden 458348 Laktationsabschlosse der 1. bis 4. Laktation von 172065 Kuhen aus 873 Vatern. Die Tiere gehorten sechs genetischen Gruppen an, die sich aus Holstein Friesen, bodenständiger Ungarischer Rasse und Kreuzungskombinationen mit unterschiedlichem HF-Anteil aus diesen Rassen zusammensetzten. Die Schătzung erfolgte mittels Mehrmerkmalsmodell. Mit Ausnahme der Korrelationen zwischen SCS und dem Eiweißanteil waren sowohl die genetischen als auch die phänotypischen Korrelationen negativ. Das galt sowohl filr die erfaßte Laktationsleistung als auch für die Testtagsdaten. Die Koeffizienten ergaben allgemein eine Erhöhung mit steigender Laktationsnummer. Die negativen Korrelationen zwischen SCS und dem Gesamt- bzw. täglichen Milchertrag, Fett- und Laktoseanteil wiesen neben der Abhängigkeit von der Laktationsnummer uberwiegend höhere Werte mit ansteigendem HF-Anteil auf. Die positiven Beziehungen zwischen SCS und Eiweißanteil ergaben tendentiell hohere Schatzwerte mit steigendem HF-Anteil.

Schlilsselwörter: Somatische Zellzahl, Korrelationen, Milchleistung, Ungarische Holstein-Friesen, HFKreuzungen

\section{Introduction}

Despite a reduction in the incidence of clinical and subclinical mastitis over the past 25 years in some developed countries (BOOTH, 1995) mastitis remains one of the most 
costly health problems of dairy cattle and a major source of economic loss to dairy farms. There are also several changes in milk yield composition that may be causes poorer cheese making properties. YOUNG et al. (1960) reported that an average value of 0.89 for the genetic correlation between SCC and clinical mastitis while a value of 0.83 obtained by AFIFI (1968). Therefore, developing dairy cattle industry is, somewhat depending on the evaluation of association between mastitis or its correlated trait $(\mathrm{SCC})$ and milk production traits accordingly. The most current studies indicated that the estimates of genetic correlations among SCC in the first 3 to 5 lactations ranged from 0.44 to 0.95 (MRODE and SWANSON, 1996). Phenotypic correlations between SCC and milk yield tended to be more negative in older lactations than in the parampious cows ranging from -.12 to -.24 (MONARDES et al,, 1984; BANOS and SHOOK, 1990). MRODE and SWANSON (1996) found that, most of reductions in milk yield production and milk composition yields or percentage are phenotyipcally correlated with increasing levels of SCC production rates. Several statistical methods and software package were used in evaluating performance in relation to SCC production. This might be the reason of the variation and inconsistently of the estimates of genetic and phenotypic correlations in different studies. Moderate or low positive estimates of genetic correlations between SCC and milk, fat, protein yields have been reported by KENNEDY et al. (1982) as $0.14,0.08,0.18$ respectively. On the other hand MONARDES et al. (1984) reported higher estimates of $0.35,0.68,0.74$ for milk, fat, and protein yields, respectively. COFFEY et al. (1986) found negative genetic correlations of SCC with milk and fat yields as -0.14 and -0.09 , respectively. While MONARDES et al. (1984) found a very high negative genetic correlation for SCC with milk, fat, or protein yields.

The aim of the present study is to figure out a reliable genetic association analysis of the (lactation and test-day measures) relationship between SCC and milk production traits in six genetic groups of Holstein-Friesian (HF) and Native Hungarian Breed (NHB) using multi trait animal model.

\section{Materials and Methods}

A total of 458348 lactation records were used for 172065 cows as daughters of 873 sires in the first four parities. Lactation and test-day somatic cell count (SCC) and milk production traits for 14329 Holstein Friesian ( $\mathrm{HF}=\mathrm{G} 6$ ) cows, 13021 Native Hungarian Breeds $(\mathrm{NHB}=\mathrm{G} 1)$ and 144715 of their crossbreds cows calving between 1993 to 1997 were provided by the local associations in Hungary. Crossbred groups involved in the present study were calssified according to HF blood, $<25 \%$ HF genes (G2), $25-50 \%$ HF genes (G3), 50-75\% HF genes (G4) and $>75 \%$ HF genes (G5). Two general data sets were used in the analysis of genetic and phenotypic association between somatic cell score and milk production traits in the first four parities. The first data set involved measures of at least 5 months and maximum observations were not more than 14 months for all studied traits. Traits involved in the $1^{\text {st }}$ data set were the actual

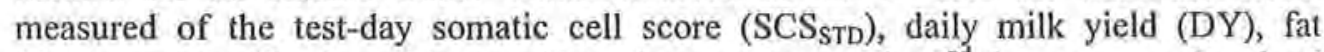
$\left(\mathrm{F}_{\mathrm{STD}}\right)$, protein $\left(\mathrm{P}_{\mathrm{STD}}\right)$, and lactose $\left(\mathrm{Lc}_{\mathrm{STD}}\right)$ percentages. The $2^{\text {nd }}$ data set were involved the weighted mean (adjusted for stage of lactation) of $\mathrm{SCS}_{\mathrm{L}}$ per lactation and the total milk yield $(M Y)$ per lactation and average of fat, protein and lactose percentages $\left(F_{L}\right.$, 
$\left.\mathrm{P}_{\mathrm{L}}, \mathrm{Lc}_{\mathrm{L}}\right)$ per lactation. Measures of somatic cell count were adjusted for calendar month of test, stage of lactation and test day milk (CHARFEDDINE et al., 1997; ZHANG et al., 1994). Cows were not required to have a $2^{\text {nd }}$ lactation to be included in the $1^{\text {st }}$ lactation analysis. All cows included in the $2^{\text {nd }}$ lactation analysis may had not a usable first lactation data but calved successively the $2^{\text {nd }}$ lactation at not more than 50 months of age.

Genetic and phenotypic correlations among the various SCS means and milk production traits in both data sets were estimated using an animal model of MTDFREML package (BOLDMAN, 1997). For an animal model that includes both animals with records and genetically related animals with no records,

$$
y=X B+X u+e
$$

Where $y$ is an $n x l$ vector (augmented to $t x l$ with the additional of a $t-n$ null vector when evaluating animals without records) of observations on the trait of interest; $X$ is an $n * p$ incidence matrix; $Z$ is a $t * t$ matrix equal to an $n * n$ identity matrix relating observations to the animals that made them and augmented by null rows and vectors for animals that are to be evaluated but have no records; $B$ is a $p * I$ vector of unknown fixed effects; $u$ is a $t * l$ vector of random breeding values, which can be partitioned into $u_{l}$, and $n * l$ vector representing animals having records and $u_{2}$, a $(t-n)$ $* I$ vector for related animals with no records; and $\mathrm{e}$ is an $n$ " $I$ vector of random
errors. Thus

$$
\begin{aligned}
& E\left[\begin{array}{l}
y \\
u \\
e
\end{array}\right]=\left[\begin{array}{l}
X B \\
0 \\
0
\end{array}\right], \\
& \text { and }
\end{aligned}
$$

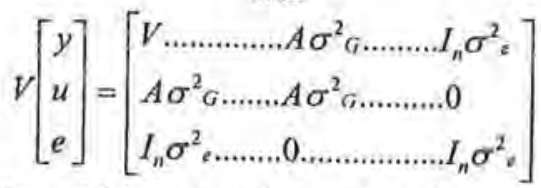

where $V=A^{-1} \sigma_{G}{ }_{G}+I_{n} \sigma^{2} e, A=$ addtive genetic relationship matrix, $\sigma_{G}^{2}=$ additive genetic variance and $\sigma^{2} e=$ residual variance.

Somatic cell count (SCC) has been transformed to SCS with the base 2 log scale as $\mathrm{SCS}=\log _{2}[3+(\mathrm{SCC} / 100)]$

that accepted by the National Co-operative Dairy Herd Improvement Program of the USA as a standard recording form for somatic cell count.

\section{Results and Discussion}

Results of Table 1 shows the estimates of $R_{\mathrm{g}}$ and $R_{\mathrm{p}}$ between all studied traits using $\mathrm{L}$ and STD data sets. The highest $R_{\mathrm{g}}$ of SCS and milk production traits obtained for $\mathrm{Lc}_{\mathrm{L}}$ $(-0.18)$, DY $(-0.13)$ and $F_{\text {STD }}(-0.13)$. These results may indicate that the increased somatic cell in milk yield are not genetically associated with low yields of milk or percentage of fat and lactose. On the other hand, the highest $R_{\mathrm{p}}$ in both data sets were obtained for SCS with milk yield. $R_{p}$ of $\operatorname{SCS}_{\mathrm{L}}$ with MY was superior by $13 \%$ than SCS $_{\text {STD }}$ with DY. Results in Table 1 shows little differences obtained between 
estimates of $\mathrm{L}$ or STD $R \mathrm{p}$ for SCS with fat and protein. This indicates that the phenotypic selection could successfully depend on production level of fat and protein to reduce level of somatic cell in milk based on results of pooled analyses either for $\mathrm{L}$ or STD data set.

Table I

Laclation (L) and sample test-day (STD) genetic (above) and phenotypic (below) correlations between different studied traits (Genetische (uber Diagonale) und phunotypische (unter Diagonale) Korrelationen untersuchter Merkmale beider Erfassungsmethoden)

\begin{tabular}{|c|c|c|c|c|c|c|c|c|c|c|c|}
\hline & MY & $F_{L}$ & $P_{L}$ & $\mathrm{LC}_{\mathrm{L}}$ & $\mathrm{SCS}_{\mathrm{L}}$ & & DY & $F_{\text {STD }}$ & $P_{\text {STD }}$ & $L C_{S T D}$ & $\mathrm{SCS}_{\text {STD }}$ \\
\hline MY & & $\begin{array}{l}-.53 \\
\text { (.11) }\end{array}$ & $\begin{array}{l}-.59 \\
(.13)\end{array}$ & $\begin{array}{l}-.21 \\
(.09)\end{array}$ & $\begin{array}{l}-.11 \\
.10\end{array}$ & DY & & $\begin{array}{c}-59 \\
(10)\end{array}$ & $\begin{array}{l}-.62 \\
(.18)\end{array}$ & $\begin{array}{l}-.29 \\
(.14)\end{array}$ & $\begin{array}{l}.13 \\
(.07)\end{array}$ \\
\hline $\mathrm{F}_{\mathrm{L}}$ & $\begin{array}{l}-29 \\
(.09)\end{array}$ & & $\begin{array}{l}.67 \\
(.18)\end{array}$ & $\begin{array}{l}.49 \\
(.09)\end{array}$ & $\begin{array}{l}.12 \\
.04\end{array}$ & $F_{\text {STD }}$ & $\begin{array}{l}-.27 \\
(.07)\end{array}$ & & $\begin{array}{l}.66 \\
(, 19)\end{array}$ & $\begin{array}{l}.50 \\
(.14)\end{array}$ & $\begin{array}{l}-.13 \\
(.08)\end{array}$ \\
\hline$P_{L}$ & $\begin{array}{l}-36 \\
(.11)\end{array}$ & $\begin{array}{l}39 \\
(.18)\end{array}$ & & $\begin{array}{l}.53 \\
(.12)\end{array}$ & $\begin{array}{l}.09 \\
.13\end{array}$ & $P_{\text {STD }}$ & $\begin{array}{l}-.33 \\
(.18)\end{array}$ & $\begin{array}{l}.38 \\
(.14)\end{array}$ & & $\begin{array}{l}.52 \\
(.12)\end{array}$ & $\begin{array}{l}.11 \\
(.04)\end{array}$ \\
\hline $\mathrm{Lc}_{\mathrm{L}}$. & $\begin{array}{l}-.33 \\
\text { (.II) }\end{array}$ & $\begin{array}{l}23 \\
(.18)\end{array}$ & $\begin{array}{l}.48 \\
(.23)\end{array}$ & & $\begin{array}{l}-.18 \\
.09\end{array}$ & $\mathrm{Le}_{\text {STD }}$ & $\begin{array}{l}-.09 \\
(.10)\end{array}$ & $\begin{array}{l}.53 \\
(.24)\end{array}$ & $\begin{array}{l}51 \\
(.12)\end{array}$ & & $\begin{array}{l}-.11 \\
(.08)\end{array}$ \\
\hline $\mathrm{SCS}_{\mathrm{L}}$ & $\begin{array}{l}-.17 \\
(.09)\end{array}$ & $\begin{array}{l}.09 \\
(.07)\end{array}$ & $\begin{array}{l}11 \\
(.04)\end{array}$ & $\begin{array}{l}.13 \\
(.10)\end{array}$ & & $\mathrm{SCS}_{\mathrm{STD}}$ & $\begin{array}{l}-15 \\
(.07)\end{array}$ & $\begin{array}{l}-.09 \\
(.11)\end{array}$ & $\begin{array}{l}.12 \\
(.07)\end{array}$ & $\begin{array}{c}-11 \\
(.08)\end{array}$ & \\
\hline
\end{tabular}

Values of SE between brackets

$R_{g}$ of fat with protein and lactose either $\mathrm{L}$ or STD are approximately similar. Little differences were obtained between $R_{\mathrm{g}}$ and $R_{\mathrm{p}}$ in both data sets of the relationship between lactose and protein. SCHUTZ et al. (1990) have taken SCS into consideration in analysis relationship between milk yield compositions, they found that genetic and phenotypic correlations between milk yield and both of $\mathrm{F} \%$ and $\mathrm{P} \%$ were negative and ranged from -.48 to -.63 but positive for $\mathrm{F} \%$ and $\mathrm{P} \%$ with SCS that ranged from .64 to 73. Also they found that some of the relationships were nearer to zero for the $3^{\text {rd }}$ and later parities, perhaps because of selection bias. Results of the present study were generally consistent with previous reports (DE JAGER and KENNEDY, 1987; HARGROVE et al., 1981; MAIJALA and HANNA, 1974). WELPER and FREEMAN (1992) found that genetic correlations for the $1^{\text {st }}$ lactation of $\mathrm{Lc} \%$ was -0.30 with MY but the corresponding estimates between MY with $\mathrm{F} \%$ and $\mathrm{P} \%$ were also negative but were larger than that found between MY and $\mathrm{Lc} \%$. While the relationship of Lc\% with both of $\mathrm{P} \%$ and $\mathrm{F} \%$ were 0.16 and 0.29 .

Phenotypic relationship of SCS with lactose either L or STD were -.13 and -.11 respectively and were in agreement with estimates in previous literature, which indicate that lactose decreased under mastitic conditions (KENNDY et al., 1982). $R_{g}$ for lactose with both of protein and fat were very high and ranged from 0.49 to 0.53 (Table 1) of both data sets. These results could permit rapid correlated genetic change. Because overproduction of lactose percentage and fat percentage are the main problems in current markets, the desired breeding goal would seem to be the increase of protein while holding fat and lactose percentage constant.

Estimates of genetic and phenotypic (co)-variances are presented in Table 2 and could be used in preparation of a suitable selection index for improving milk production and increasing ability of mastitis resistance through reducing level of somatic cell in milk yield. 
Table 2

Lactation and sample test-day genetic (above) and phenotypic (below) covariances between different studied traits (Kovarianzen zu Tabelle 1)

\begin{tabular}{|c|c|c|c|c|c|c|c|c|c|c|c|}
\hline & MY & $\mathrm{F}_{\mathrm{L}}$ & $\mathrm{P}_{\mathrm{L}}$ & $L c_{L}$ & $\mathrm{SCS}_{\mathrm{L}}$ & & DY & $F_{\text {STD }}$ & $P_{S T D}$ & $\mathrm{Lc}_{\text {sTD }}$ & $\mathrm{SCS}_{\mathrm{STD}}$ \\
\hline \multicolumn{6}{|c|}{ Lactational estimates } & \multicolumn{6}{|c|}{ Sample test-day estimates } \\
\hline MY & & -843.4 & -420.4 & -351.7 & -5016 & DY & & -4.1 & -6.9 & -6.2 & 77.6 \\
\hline $\mathrm{F}_{\mathrm{L}}$ & -836.4 & & 1.9 & 3.4 & -22.7 & $F_{\text {STD }}$ & 10.6 & & 2.1 & 3.1 & -22.3 \\
\hline $\mathrm{P}_{\mathrm{L}}$ & -1438 & 6.7 & & 5.2 & 24.1 & $\mathrm{P}_{\mathrm{STD}}$ & -21.7 & 7.6 & & 5.2 & 30.8 \\
\hline $\mathrm{Lc}_{\mathrm{L}}$ & -3207 & 9.6 & 27.9 & & -113.5 & $L c_{\text {STD }}$ & -38.3 & 19.9 & 32.0 & & -58.3 \\
\hline $\operatorname{SCS}_{\mathrm{L}}$ & -39440 & -90.4 & 152.9 & -439.8 & & $\operatorname{SCS}_{\mathrm{STD}}$ & -466.2 & -84.7 & 189.4 & -326.4 & \\
\hline
\end{tabular}

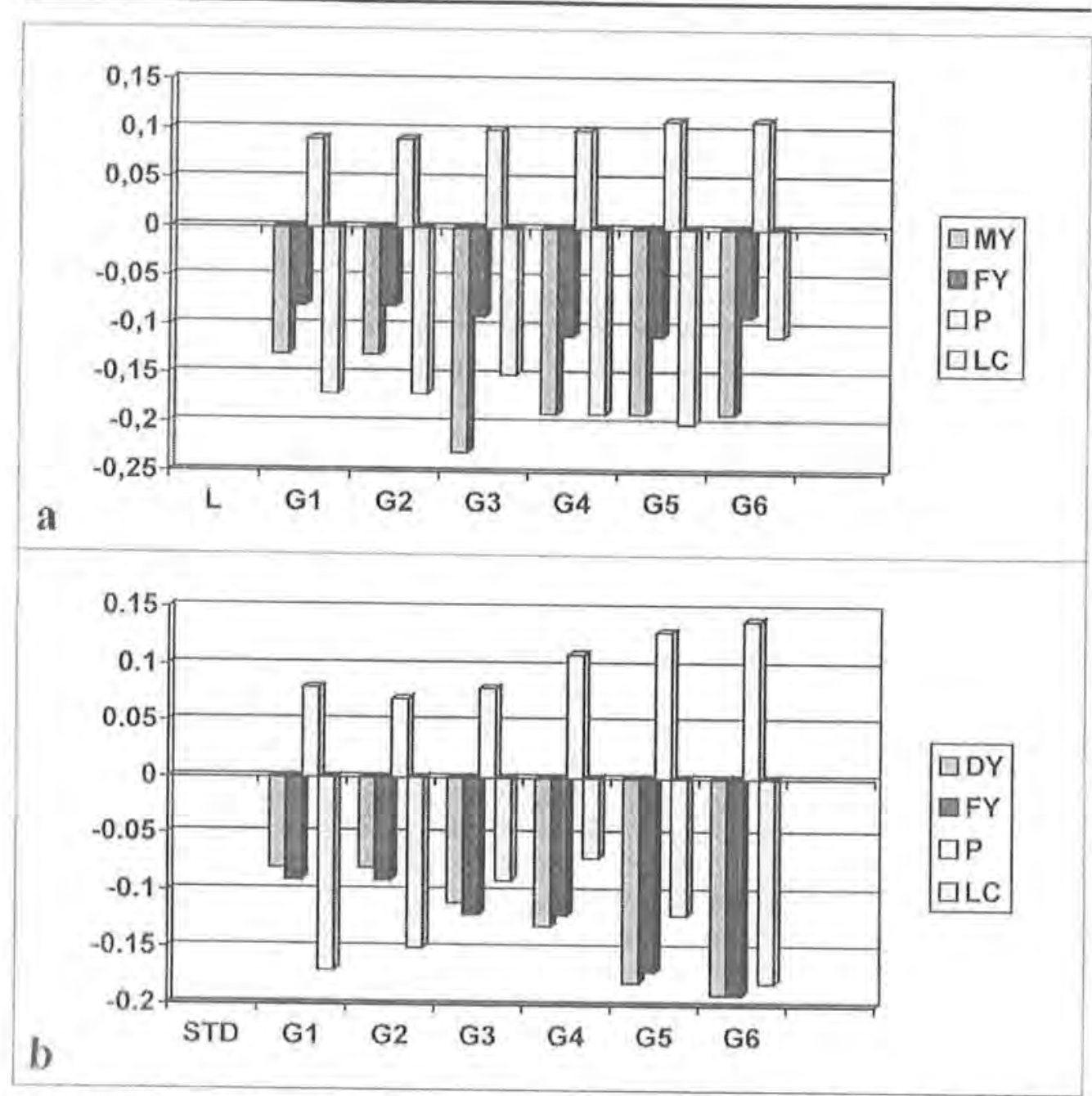

Fig. 1: Lactation (L) and sample test-day (STD) phenotypic correlation between SCS and milk production traits in different genetic groups (Phänotypische Korrelationen zwischen SCS und Milchleistungsmerkmalen unterschiedlicher genetischer Gruppen)

G1:HNB, G2: $25 \% \mathrm{HF}$, G3: $25-50 \% \mathrm{HF}, \mathrm{G} 4: 50-75 \% \mathrm{HF}, \mathrm{G} 5>75 \% \mathrm{HF}$, G6: HF 


\section{Correlations of SCS with milk production traits within genetic groups}

Phenotypic associations $\left(R_{p}\right)$ of SCS with milk production traits are in Figures (1a \& 1b). Phenotypic estimates of $\mathrm{SCS}_{\mathrm{L}}$ with $\mathrm{MY}$ and $\mathrm{Lc}_{\mathrm{L}}$ (Fig.I-a) in some crossbreds were higher than the purebreds. While the corresponding obtained STD phenotypic estimates were superior for $\mathrm{HF}$ purebred than $\mathrm{NHB}$ and crossbred of low HF\% genes. Results in Fig. (1b), shows that there is association in changing rate of $R_{p}$ for SCS STD with DY and $\mathrm{F}_{\mathrm{STD}}$ across different genetic groups. Increasing $R_{p}$ of SCS $\mathrm{STD}_{\mathrm{ST}}$ with $\mathrm{F}_{\mathrm{STD}}$

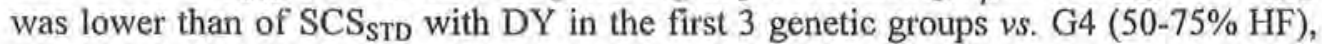
G5 (>75\%HF). On the other hand, $R_{p}$ of SCS $_{\text {STD }}$ with DY and F STD $_{\text {TID }}$ were completely similar in HF puerbred. $R_{p}$ (Fig, 1-b) estimates of SCS $_{\mathrm{STD}}$ with $\mathrm{P}_{\mathrm{STD}}$ increased progressively with increasing HF\% genes than lactation estimates (Fig. 1-a). Results in Figures 1-a and 1-b, shows that STD statistical model obtained a real differences in estimates of $R_{p}$ of SCS STD $_{\text {with }} \mathrm{F}_{\mathrm{STD}}$ and DY compared to L-statistical model especially for $\mathrm{HF}$ purebred and crossbred of high $\mathrm{HF} \%$ genes.

Genetic association $\left(R_{g}\right)$ between SCS and milk production traits are in Figures (2a, \& $2 \mathrm{~b})$. Estimates of $R_{\mathrm{g}}$ of SCS with protein either L or STD were near to zero value for $\mathrm{NHB}$ and $\mathrm{G}_{2}(\leq 25 \% \mathrm{HF})$. On the other hand this relationship advanced with increasing HF\% genes in both data sets. Estimates of $R_{g}$ for $S_{C S}$ with MY, $F_{L}$, and $L c_{L}$ declined with increasing $\mathrm{HF} \%$ genes. Strong reduction of $R_{g}$ for $S C S_{L}$ with $\mathrm{Lc}_{\mathrm{L}}$ obtained form $\mathrm{G}_{3}(25-50 \% \mathrm{HF})$ to $\mathrm{HF}$ after silgtly increase from NHB. On the other hand slow decline of $R_{\mathrm{g}}$ for $\mathrm{SCS}_{\mathrm{L}}$ with $\mathrm{MY}$ obtained from NHB to $\mathrm{G}_{3}(25-50 \% \mathrm{HF})$ followed by great decline to $\mathrm{HF}$. A moderate decline was obtained for $R_{g}$ considering $\mathrm{SCS}_{\mathrm{L}}$ with $F_{L}$ toward HF, Lactation statistical model generate the highest estimates of $R_{g}$ of SCS with milk production traits.

In general, lactation statistical model may be more reliable for analysis genetic and phenotypic relationship of SCS with milk production traits using the pooled records of both data sets.

\section{Correlations of SCS with milk production within parity}

Genetic and phenotypic association between milk production traits and SCS in the first four parities are presented in the Table $3 . R_{g}$ estimates of $\mathrm{SCS}_{\mathrm{L}}$ with milk production traits were mostly negative except that for $\mathrm{P}_{\mathrm{L}}$ and $\mathrm{MY}$ in the $1^{\text {st }}$ two parities. Trends of correlation estimates with advancing order of lactation were I) $R_{g}$ increased for SCS with MY (L and STD) and $R_{p}$ for SCS with protein (L and STD) with advancing parity, II) $R_{g}$ of SCS with fat (L and STD) and $R_{p}$ of SCS STD $_{\text {with F FTD decreased with }}$ advancing parity, III) up word curve obtained for $R_{p}$ of SCS with $\mathrm{F}_{\mathrm{L}}, \mathrm{P}_{\mathrm{L}}, \mathrm{Lc} \mathrm{L}$, and $R_{g}$ with $\mathrm{P}_{\mathrm{STD}}$, IV) down word curve was obtained for $R_{p}$ of $\mathrm{SCS}_{\mathrm{STD}}$ with DY. Hungarian reports on correlations between milk yield and somatic cells are frequent in common. Most published studies found that the genetic correlations of MY with SCS within the early lactations can be considered unfavorable (KENNEDY et al., 1982; MONARDES et al., 1985; BANOS and SHOOK, 1990) with estimates which were ranged from 0.12 to 0.48 . Whereas several reports have found a favorable negative correlations within the $2^{\text {nd }}$ parity and in late lactations (MONARDES and HAYES, 1985; SCHUTZ et al., 1990) that ranged between 0.06 to 0.19 . Estimates of the present study are in agreement with reports of favorable correlations. 


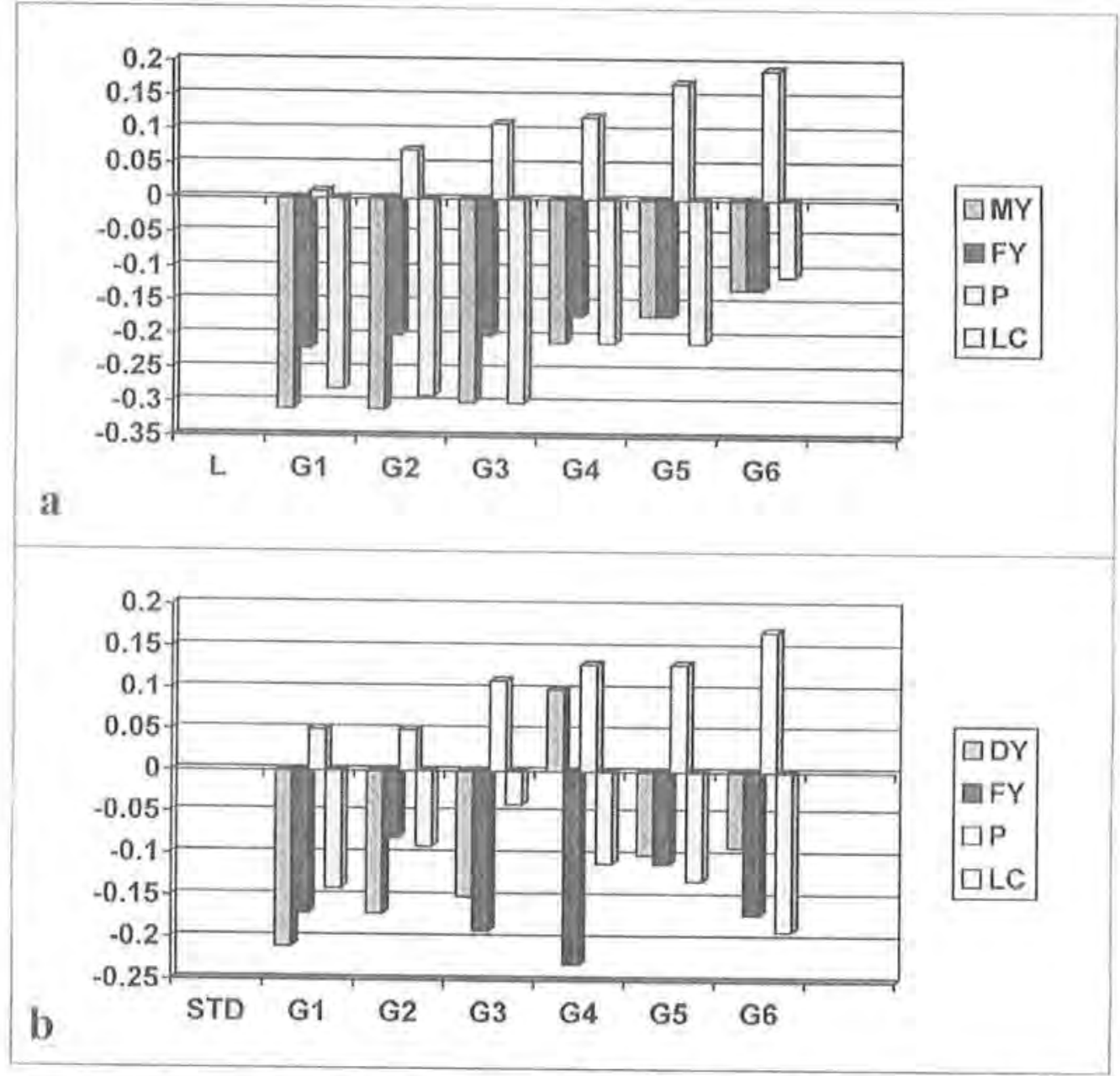

Fig. 2: Lactational (L) and sample test-day (STD) genetic correlation between SCS and milk production traits in different genetic groups (Genetische Korrelationen zwischen SCS und Milchleistungsmerkmalen unterschiedlicher genetischer Gruppen)

G1:HNB, G2: $25 \% H F$, G3: $25-50 \% H F$, G4: 50-75\%HF, GS >75\%HF, G6: HF

The highest $R_{g}$ were obtained for $\mathrm{SCS}_{\mathrm{L}}$ with $\mathrm{Lc}_{\mathrm{L}}, \mathrm{F}_{\mathrm{L}}, \mathrm{MY}$ and $\mathrm{P}_{\mathrm{L}}:-.18,-.17,-.14$ and 0.11 in the $1^{\text {st }}, 1^{\text {st }}, 4^{\text {th }}$, and $4^{\text {th }}$ parities, respectively (Table 3 ). While $R_{g}$ estimates were $-.16, .13, .13$ and -.13 in the $4^{\text {th }}, 1^{\text {st }}, 2^{\text {nd }}, 1^{\text {st }}$ parities for DY, F $F_{S T D}, P_{S T D}$ and Lc STD $_{\text {ST }}$ respectively. These results indicate that, expected correlated response in milk production through selection against SCC will be more efficient using lactation data set. On the other hand inclusion fat and protein in selection against SCS is not suggested. Because of relationship between fat and protein are positive (Table 1), great depression in these component will occur. Schutz et al. (1990) found that, genetic correlations between SCS and MY ranged from -.15 to 0.28 in different lactation and they suggested that mastitis, as indicated by SCS, is more common during $1^{\text {st }}$ lactations of cows with sires that transmit higher milk yield, perhaps because of the 
stress from high productivity of milk.

The highest $R_{p}$ either L or STD were presented mainly in the $1^{\text {st }}$ and $4^{\text {th }}$ parities and differences between these estimates were very little. This indicates that using analysis of separate parties may reduce the error of prediction than that for the pooled estimates. Trends of some relationships either genetic or phenotypic of L and STD data sets varied between up and down across parities (Table 3 ).

Table 3

Lactation (L) and sample test-day (STD) genetic and phenotypic correlations between SCS and milk production traits per parity (Genetische und phănotypische Korrelationen zwischen SCS und Milchleistungsmerkmalen in Abhängigkeit von der Laktationsnummer)

\begin{tabular}{|c|c|c|c|c|c|c|c|c|c|}
\hline \multicolumn{6}{|c|}{ Genetic correlations } & \multicolumn{4}{|c|}{ Phenotypic correlations } \\
\hline \multirow[b]{2}{*}{ Parity } & \multirow[b]{2}{*}{ MY } & \multirow[b]{2}{*}{$F_{L}$} & \multirow[b]{2}{*}{$P_{t}$} & \multicolumn{3}{|c|}{ Lactational estimates } & \multirow[b]{2}{*}{$F_{L}$} & \multirow[b]{2}{*}{$P_{L}$} & \multirow[b]{2}{*}{$L c_{L}$} \\
\hline & & & & $\mathrm{Lc}_{\mathrm{L}}$ & Parity & MY & & & \\
\hline \multirow[t]{2}{*}{$1^{n t}$} & 0.09 & -0.17 & 0.09 & -0.18 & $1^{11}$ & -0.19 & -0.04 & 0.09 & -0.09 \\
\hline & $(.01)$ & $(.02)$ & $(.01)$ & $(.09)$ & & $(.04)$ & $(.02)$ & $(.01)$ & $(.18)$ \\
\hline \multirow[t]{2}{*}{$2^{\text {nd }}$} & 0,09 & -0.15 & 0.09 & -0.13 & $2^{\text {nd }}$ & -0.12 & -0.09 & 0.11 & -0.12 \\
\hline & $(.11)$ & $(.04)$ & $(.01)$ & $(.04)$ & & $(.09)$ & $(.02)$ & $(.06)$ & $(.11)$ \\
\hline \multirow[t]{2}{*}{$3^{\text {rd }}$} & -0.12 & -0.15 & 0.10 & -0.15 & $3^{\text {rd }}$ & -0.15 & -0.08 & 0.11 & -0.19 \\
\hline & $(.04)$ & $(.04)$ & $(.04)$ & $(.02)$ & & $(.03)$ & $(.02)$ & $(.06)$ & $(.02)$ \\
\hline \multirow[t]{4}{*}{$4^{\text {th }}$} & -0.14 & -0.10 & 0.11 & -0.14 & $4^{\text {th }}$ & -0.10 & -0.11 & 0.08 & -0.17 \\
\hline & $(.11)$ & $(.07)$ & $(.11)$ & $(.09)$ & & $(.03)$ & $(.05)$ & $(.14)$ & $(.03)$ \\
\hline & \multicolumn{9}{|c|}{ Sample test-day estimates } \\
\hline & DY & $F_{S I D}$ & $P_{\text {STD }}$ & $\mathrm{Lc}_{\mathrm{STD}}$ & & DY & $F_{\text {STD }}$ & $P_{\text {STD }}$ & $L_{\text {STD }}$ \\
\hline \multirow[t]{2}{*}{$1^{s t}$} & 0.10 & 0.13 & 0.10 & -0.13 & $1^{41}$ & -0.14 & -0.11 & 0.07 & -0.12 \\
\hline & $(.11)$ & $(.04)$ & $(.04)$ & $(.07)$ & & $(.07)$ & $(.03)$ & $(.01)$ & $(, 09)$ \\
\hline \multirow[t]{2}{*}{$2^{\text {nd }}$} & -0.12 & -0.13 & 0.13 & -0.08 & $2^{\text {nd }}$ & -0.11 & -0.11 & 0.07 & -0.08 \\
\hline & $(07)$ & $(.07)$ & $(.01)$ & $(.01)$ & & $(, 08)$ & $(.07)$ & $(.05)$ & $(.08)$ \\
\hline \multirow[t]{2}{*}{$3^{\text {zd }}$} & -0.14 & -0.10 & 0.12 & -0.12 & $3^{\mathrm{rd}}$ & -0.12 & -0.09 & 0.11 & -0.11 \\
\hline & $(.01)$ & $(.03)$ & $(.09)$ & $(.02)$ & & $(.01)$ & $(.01)$ & $(.03)$ & $(.07)$ \\
\hline \multirow[t]{2}{*}{$4^{b}$} & -0.16 & -0.08 & 0.08 & -0.04 & $4^{\text {th }}$ & -0.20 & -0.07 & 0.12 & -0.07 \\
\hline & $(.07)$ & (.11) & (.11) & $(.01)$ & & $(, 11)$ & $(.09)$ & $(.09)$ & $(.04)$ \\
\hline
\end{tabular}

\section{Correlations between SCS and milk yield /genetic groups / parities}

Estimates of $R_{p} \& R_{g}$ of SCS with MY and DY in different genetic groups across parities are presented in Table 4. Most of estimates were negative. All positive $R_{g}$ were completely corresponded to negative $R_{p}$ but these results are to some extent confusing. Apparently, cows with a genetic capacity for higher milk yield are genetically more predisposed to mastitis, possibly from the physical stress of increased yield, but incidence of subclinical or clinical mastitis reduces milk and protein yield. Phenotypic correlation reflects both environmental and genetic causes of correlations. Thus, phenotypic MY is decreased, but the genetic ability of the cow to produce milk is constant.

Most of lactation $R_{g}$ in the present study were very low but not essentially close near zero. The highest lactation $R_{p}>-0.20$ were obtained for $\mathrm{HF}, \mathrm{NHB}$, and $>75 \% \mathrm{HF}$ genes in the $1^{\text {st }}, 4^{\text {th }}$ and $2^{\text {nd }}$ parity, respectively. In General the highest correlation estimates of SCS with milk yield mostly were presented in the $4^{\text {th }}$ parity for HF and NHB. While crossbreeds attained moderate estimates in deferent parities. Enormous differences between correlations of MY with SCS per parity per genetic group may suggest that SCS early and late in life may be genetically different traits, implying that selection in 
the early lactations could be more effective to reduce SCS and increase mastitis resistance. Schutz et al. (1990) reported that behavior of SCS was different in the $1^{\text {st }}$ parity than subsequent parities, suggesting that SCS may respond to different stimuli early versus late in life.

The obvious trend of changed correlation estimates were obtained for $\mathrm{L} R_{\mathrm{g}}$ of SCS with MY that progressively advanced with increasing percentage of HF genes within $1^{\text {st }}$ and $2^{\text {nd }}$ parity. While in the $3^{\text {rd }}$ and the $4^{\text {th }}$ parities only $\mathrm{HF}$ and $>75 \mathrm{HF}$ had the highest $\mathrm{L} R_{\mathrm{g}}$. On the other side, estimates of STD $R_{\mathrm{p}}$ decreased with increasing percentage of HF genes. Differences among STD $R_{g}$ within the $1^{\text {st }}$ parity with advancing percentage of $\mathrm{HF}$ genes were very little comparable with those in other parities. Differences between estimates with advancing parities may be a reflecting of true genetic differences across all genetic groups used in the present study.

Table 4

Estimates correlations between somatic cell score and milk production for all genetic groups in different parities (Korrelationen zwischen SCS und Milchleistung unterschiedlicher genetischer Gruppen und
Laktationsnummern)

\begin{tabular}{|c|c|c|c|c|c|c|c|c|c|c|c|c|c|}
\hline \multirow[b]{2}{*}{ 总 } & \multicolumn{6}{|c|}{ Genetic correlations } & \multicolumn{7}{|c|}{ Phenotypic correlations } \\
\hline & 罢 & $\begin{array}{l}\text { 訔 } \\
\text { 总 } \\
\text { 。 }\end{array}$ & $\begin{array}{l}\text { 岕 } \\
\text { 号 } \\
\text { ஸे } \\
\text { ஸे }\end{array}$ & $\begin{array}{l}\text { 岑 } \\
\text { 令 } \\
\text { †े }\end{array}$ & $\begin{array}{l}\frac{a}{7} \\
\text { o } \\
\text { in } \\
\end{array}$ & 㞬 & 总 & 号 & 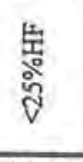 & $\begin{array}{l}\text { 岑 } \\
\text { 号 } \\
\text { ปิ }\end{array}$ & $\begin{array}{l}\text { 营 } \\
\text { 总 } \\
\text { 总 }\end{array}$ & $\begin{array}{l}\text { 筕 } \\
\stackrel{5}{\wedge} \\
\stackrel{1}{\wedge}\end{array}$ & 㞬 \\
\hline & \multicolumn{13}{|c|}{ Lactational estimates of SCS with MY } \\
\hline $1^{\text {It }}$ & $\begin{array}{c}.07 \\
(.01)\end{array}$ & $\begin{array}{l}-.09 \\
(.03)\end{array}$ & $\begin{array}{l}-.09 \\
(.10)\end{array}$ & $\begin{array}{l}11 \\
(.07)\end{array}$ & $\begin{array}{l}.13 \\
(.07)\end{array}$ & $\begin{array}{l}.13 \\
(.09)\end{array}$ & $1^{\text {nt }}$ & $\begin{array}{l}-.12 \\
(.06)\end{array}$ & $\begin{array}{l}-14 \\
(.09)\end{array}$ & $\begin{array}{l}-.09 \\
(.09)\end{array}$ & $\begin{array}{l}.12 \\
(.18)\end{array}$ & $\begin{array}{l}-.18 \\
(.20)\end{array}$ & $\begin{array}{l}-.22 \\
(.09)\end{array}$ \\
\hline $2^{\text {nd }}$ & $\begin{array}{l}-.07 \\
(.01)\end{array}$ & $\begin{array}{l}-.08 \\
(.03)\end{array}$ & $\begin{array}{l}-.09 \\
(.04)\end{array}$ & $\begin{array}{l}-.09 \\
(.03)\end{array}$ & $\begin{array}{l}-13 \\
(.11)\end{array}$ & $\begin{array}{l}-.15 \\
(.07)\end{array}$ & $2^{\text {nd }}$ & $\begin{array}{l}-.15 \\
(.07)\end{array}$ & $\begin{array}{l}-.09 \\
(.07)\end{array}$ & $\begin{array}{l}-10 \\
(.09)\end{array}$ & $\begin{array}{l}-.13 \\
(.12)\end{array}$ & $\begin{array}{l}-.22 \\
(.11)\end{array}$ & $\begin{array}{l}-18 \\
(.11)\end{array}$ \\
\hline $3^{\text {rd }}$ & $\begin{array}{l}.09 \\
(.10)\end{array}$ & $\begin{array}{l}-.07 \\
(.07)\end{array}$ & $\begin{array}{l}12 \\
(.07)\end{array}$ & $\begin{array}{l}.10 \\
(.01)\end{array}$ & $\begin{array}{l}-.13 \\
(.09)\end{array}$ & $\begin{array}{l}-.17 \\
(.07)\end{array}$ & $3^{\text {rd }}$ & $\begin{array}{l}-17 \\
(.06)\end{array}$ & $\begin{array}{l}-.17 \\
(.05)\end{array}$ & $\begin{array}{l}-.13 \\
(.10)\end{array}$ & $\begin{array}{l}-15 \\
(.07)\end{array}$ & $\begin{array}{l}-.15 \\
(.09)\end{array}$ & $\begin{array}{l}.14 \\
(.10)\end{array}$ \\
\hline \multirow[t]{2}{*}{$4^{\text {th }}$} & $\begin{array}{l}-.09 \\
(.11)\end{array}$ & $\begin{array}{l}-.06 \\
(.07)\end{array}$ & $\begin{array}{l}.12 \\
(.04)\end{array}$ & $\begin{array}{l}11 \\
(.01)\end{array}$ & $\begin{array}{l}-.13 \\
(.07)\end{array}$ & $\begin{array}{l}-.11 \\
(.06)\end{array}$ & $4^{\text {th }}$ & $\begin{array}{l}-.23 \\
(.12)\end{array}$ & $\begin{array}{l}-12 \\
(.06)\end{array}$ & $\begin{array}{l}-12 \\
(.12)\end{array}$ & $\begin{array}{l}-.09 \\
(.04)\end{array}$ & $\begin{array}{l}-.13 \\
(.07)\end{array}$ & $\begin{array}{l}-.11 \\
(.07)\end{array}$ \\
\hline & \multicolumn{13}{|c|}{ Sample test-day estimates of SCS with DY } \\
\hline $1^{\text {st }}$ & $\begin{array}{c}.13 \\
(.08)\end{array}$ & $\begin{array}{c}.14 \\
(.10)\end{array}$ & $\begin{array}{l}14 \\
(, 12)\end{array}$ & $\begin{array}{l}.14 \\
(.09)\end{array}$ & $\begin{array}{l}.11 \\
(.04)\end{array}$ & $\begin{array}{l}.08 \\
(.01)\end{array}$ & $1^{\prime \prime}$ & $\begin{array}{l}-.22 \\
(.07)\end{array}$ & $\begin{array}{l}-.20 \\
(.09)\end{array}$ & $\begin{array}{l}-.20 \\
(.11)\end{array}$ & $\begin{array}{l}-.15 \\
(.11)\end{array}$ & $\begin{array}{l}-.14 \\
(18\end{array}$ & $\begin{array}{l}-.11 \\
(.01)\end{array}$ \\
\hline $2^{\text {nd }}$ & $\begin{array}{l}-.13 \\
(.07)\end{array}$ & $\begin{array}{l}-13 \\
(.07)\end{array}$ & $\begin{array}{l}-17 \\
(.18)\end{array}$ & $\begin{array}{l}18 \\
(.04)\end{array}$ & $\begin{array}{l}-.14 \\
(.02)\end{array}$ & $\begin{array}{l}-.15 \\
(.11)\end{array}$ & $2^{\text {nd }}$ & $\begin{array}{l}-20 \\
(.10)\end{array}$ & $\begin{array}{l}-.21 \\
(.07)\end{array}$ & $\begin{array}{l}-.19 \\
(.04)\end{array}$ & $\begin{array}{l}.17 \\
(.02)\end{array}$ & $\begin{array}{l}-.14 \\
(.07)\end{array}$ & $\begin{array}{l}-.13 \\
(.11)\end{array}$ \\
\hline $3^{\text {nt }}$ & $\begin{array}{l}.09 \\
(.07)\end{array}$ & $\begin{array}{l}-.11 \\
(.01)\end{array}$ & $\begin{array}{l}-11 \\
(.04)\end{array}$ & $\begin{array}{l}.08 \\
(.03)\end{array}$ & $\begin{array}{l}-.08 \\
(.07)\end{array}$ & $\begin{array}{l}-.14 \\
(.17)\end{array}$ & $3^{\text {rd }}$ & $\begin{array}{l}-.20 \\
(.12)\end{array}$ & $\begin{array}{l}-.24 \\
(.09)\end{array}$ & $\begin{array}{l}-.18 \\
(.09)\end{array}$ & $\begin{array}{l}-. \mathrm{I1} \\
(.01)\end{array}$ & $\begin{array}{l}-.15 \\
(.03)\end{array}$ & $\begin{array}{l}-.17 \\
\text { (.II) }\end{array}$ \\
\hline $4^{\text {th }}$ & $\begin{array}{l}-.22 \\
(.11)\end{array}$ & $\begin{array}{l}-.17 \\
(.07)\end{array}$ & $\begin{array}{l}-.10 \\
(.02)\end{array}$ & $\begin{array}{l}-.12 \\
(.06)\end{array}$ & $\begin{array}{l}-18 \\
(.11)\end{array}$ & $\begin{array}{l}-.25 \\
(.10)\end{array}$ & $4^{\text {th }}$ & $\begin{array}{l}-18 \\
(.09)\end{array}$ & $\begin{array}{l}-14 \\
(.08)\end{array}$ & $\begin{array}{l}-.13 \\
(.07)\end{array}$ & $\begin{array}{l}-.13 \\
(.11)\end{array}$ & $\begin{array}{l}-.16 \\
(.07)\end{array}$ & $\begin{array}{l}-24 \\
(.11)\end{array}$ \\
\hline
\end{tabular}

\section{Correlation between SCS and fat percentage/genetic group/ parity}

Table 5 shows estimate of L and STD either $R_{\mathrm{g}}$ or $R_{\mathrm{p}}$ of SCS with fat across parities in deferent genetic groups. Estimates of $\mathrm{L} R_{\mathrm{g}}$ in deferent parities were mostly higher than the corresponding estimates for MY. This may indicate that contribution of fat percentage with SCS in selection indexes constructions for improving general profitability of dairy cattle will be more efficient than contribution MY only. The highest genetic correlation either STD or L of SCS with fat was presented in the $4^{\text {th }}$ 
parity (Table 5). The results are similar to those obtained for relationship of MY with $\mathrm{SCS}$. Differences between the highest $R_{\mathrm{g}}$ of $\mathrm{SCS}_{\mathrm{L}}$ with MY and $\mathrm{SCS}_{\mathrm{L}}$ with $\mathrm{F}_{\mathrm{L}}$ was very high than the corresponding STD estimates. This may lead us to suggest that measures of STD rather than $\mathrm{L}$ ones could be used as a reliable prediction indicator of the production as far as one or more component of milk production traits are missed in monthly observations. Results in Table 5 shows that $\mathrm{L} R_{g}$ increased with parity for $\mathrm{NHB},<25 \%$ and $25-50 \% \mathrm{HF}$ genes. On the other hand, $\mathrm{HF}, 50-75 \% \mathrm{HF}$, and $>75 \%$ HF had STD $R_{g}$ progressively advancing with increasing order of lactation. This indicates that, STD measures could reflect the accurate value of genetic makeup than $\mathrm{L}$-one. Differences between estimates of $\mathrm{L} R_{\mathrm{p}}$ with advancing order of lactation were clearer within NHB and HF than within crossbreeds. While the corresponding STD $R_{\mathrm{p}}$ differences were clearness for NHB and crossbreeds of low HF\% genes. Fluctuation in the correlation estimates either negative or positive of SCS with fat refer to some factors which may control this relationship.

Table 5

Estimates correlations between SCS and fat percentage for all genetic groups in different parities (Korrelationen zwischen SCS und Fettgehalt unterschiedlicher genetischer Gruppen und Laktationsnummern)

\begin{tabular}{|c|c|c|c|c|c|c|c|c|c|c|c|c|c|}
\hline \multirow[b]{2}{*}{ 总 } & \multicolumn{5}{|c|}{ Genetic correlations } & & \multicolumn{7}{|c|}{ Phenotypic correlations } \\
\hline & $\sum^{\infty}$ & 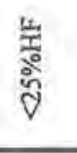 & 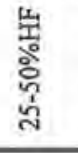 & $\begin{array}{l}\text { 容 } \\
\text { 今े } \\
\text { ஸे }\end{array}$ & 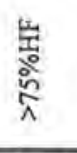 & 崖 & 高 & 空 & $\begin{array}{l}\text { 愛 } \\
\text { ป }\end{array}$ & 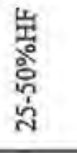 &  & 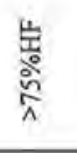 & 崖 \\
\hline & \multicolumn{13}{|c|}{ Lactation estimates of SCS with $F_{1}$} \\
\hline $1^{11}$ & $\begin{array}{l}-19 \\
(.02)\end{array}$ & $\begin{array}{l}-13 \\
(.14)\end{array}$ & $\begin{array}{l}-.11 \\
(.03)\end{array}$ & $\begin{array}{l}-.18 \\
(.09)\end{array}$ & $\begin{array}{l}.08 \\
(.11)\end{array}$ & $\begin{array}{l}-.19 \\
(.02)\end{array}$ & $1^{\text {st }}$ & $\begin{array}{l}.11 \\
(.04)\end{array}$ & $\begin{array}{l}-.12 \\
(.03)\end{array}$ & $\begin{array}{l}-.10 \\
(.02)\end{array}$ & $\begin{array}{l}-.10 \\
(.03)\end{array}$ & $\begin{array}{l}-.05 \\
(.02)\end{array}$ & $\begin{array}{l}-.05 \\
(.03)\end{array}$ \\
\hline $2^{\text {nd }}$ & $\begin{array}{l}-20 \\
(.01)\end{array}$ & $\begin{array}{c}-113 \\
(111)\end{array}$ & $\begin{array}{l}-14 \\
(.09)\end{array}$ & $\begin{array}{l}-.20 \\
(.07)\end{array}$ & $\begin{array}{l}.15 \\
(.09)\end{array}$ & $\begin{array}{l}-.15 \\
(.09)\end{array}$ & $2^{\text {nd }}$ & $\begin{array}{l}-11 \\
(.03)\end{array}$ & $\begin{array}{l}-.04 \\
(.01)\end{array}$ & $\begin{array}{l}-.12 \\
(.03)\end{array}$ & $\begin{array}{l}-11 \\
(.05)\end{array}$ & $\begin{array}{l}-.06 \\
(.06)\end{array}$ & $\begin{array}{l}-.08 \\
(.09)\end{array}$ \\
\hline $3^{\text {rd }}$ & $\begin{array}{l}-.24 \\
(.09)\end{array}$ & $\begin{array}{c}-19 \\
(.07)\end{array}$ & $\begin{array}{l}19 \\
(.08)\end{array}$ & $\begin{array}{l}-13 \\
(.08)\end{array}$ & $\begin{array}{l}.09 \\
(.07)\end{array}$ & $\begin{array}{l}.10 \\
(.03)\end{array}$ & $3^{\text {rd }}$ & $\begin{array}{l}-11 \\
(.09)\end{array}$ & $\begin{array}{l}-.06 \\
(.06)\end{array}$ & $\begin{array}{l}-.08 \\
(.06)\end{array}$ & $\begin{array}{l}-12 \\
(.04)\end{array}$ & $\begin{array}{l}-.08 \\
(.03)\end{array}$ & $\begin{array}{l}-.08 \\
(.03)\end{array}$ \\
\hline \multirow[t]{2}{*}{$4^{\mathrm{th}}$} & $\begin{array}{l}-.25 \\
(.11)\end{array}$ & $\begin{array}{l}-.27 \\
(.06)\end{array}$ & $\begin{array}{l}-.25 \\
(.08)\end{array}$ & $\begin{array}{l}.08 \\
(.03)\end{array}$ & $\begin{array}{l}.08 \\
(.02)\end{array}$ & $\begin{array}{l}-11 \\
(.03)\end{array}$ & $4^{\text {th }}$ & $\begin{array}{l}.04 \\
(.06)\end{array}$ & $\begin{array}{l}-.09 \\
(.04)\end{array}$ & $\begin{array}{l}.07 \\
(.04)\end{array}$ & $\begin{array}{l}-08 \\
(.04)\end{array}$ & $\begin{array}{l}-.08 \\
(.09)\end{array}$ & $\begin{array}{l}12 \\
(.02)\end{array}$ \\
\hline & \multicolumn{13}{|c|}{ Sample test-day estimates } \\
\hline $1^{\text {"II }}$ & $\begin{array}{l}-, 22 \\
(.12)\end{array}$ & $\begin{array}{l}-10 \\
(.12)\end{array}$ & $\begin{array}{l}-.20 \\
(18)\end{array}$ & $\begin{array}{l}-.11 \\
(.07)\end{array}$ & $\begin{array}{l}.05 \\
(.11)\end{array}$ & $\begin{array}{l}-10 \\
(.02)\end{array}$ & $1^{11}$ & $\begin{array}{l}-.04 \\
(.02)\end{array}$ & $\begin{array}{l}-.05 \\
(.03)\end{array}$ & $\begin{array}{l}.08 \\
(.09)\end{array}$ & $\begin{array}{l}-.09 \\
(.03)\end{array}$ & $\begin{array}{l}-.11 \\
(.03)\end{array}$ & $\begin{array}{l}-.13 \\
(.06)\end{array}$ \\
\hline $2^{\text {nd }}$ & $\begin{array}{l}-19 \\
(.11)\end{array}$ & $\begin{array}{l}-.11 \\
(.05)\end{array}$ & $\begin{array}{l}-.22 \\
(.10)\end{array}$ & $\begin{array}{l}-.13 \\
(.06)\end{array}$ & $\begin{array}{l}.06 \\
(.02)\end{array}$ & $\begin{array}{l}-12 \\
(.08)\end{array}$ & $2^{\text {nd }}$ & $\begin{array}{l}-.04 \\
(.01)\end{array}$ & $\begin{array}{l}-.06 \\
(.03)\end{array}$ & $\begin{array}{l}-.08 \\
(.03)\end{array}$ & $\begin{array}{l}-12 \\
(.07)\end{array}$ & $\begin{array}{l}-.12 \\
(.09)\end{array}$ & $\begin{array}{l}-.19 \\
(.10)\end{array}$ \\
\hline $3^{\text {td }}$ & $\begin{array}{l}-.11 \\
(.03)\end{array}$ & $\begin{array}{l}-.08 \\
(.09)\end{array}$ & $\begin{array}{l}-.11 \\
(.09)\end{array}$ & $\begin{array}{l}.27 \\
(.07)\end{array}$ & $\begin{array}{l}-.11 \\
(.02)\end{array}$ & $\begin{array}{l}-19 \\
(.07)\end{array}$ & $3^{\text {rd }}$ & $\begin{array}{l}.09 \\
(.03)\end{array}$ & $\begin{array}{l}-11 \\
(.06)\end{array}$ & $\begin{array}{l}111 \\
(.07)\end{array}$ & $\begin{array}{l}-.04 \\
(.03)\end{array}$ & $\begin{array}{l}-.15 \\
(.08)\end{array}$ & $\begin{array}{l}-.22 \\
(.11)\end{array}$ \\
\hline $4^{\mathrm{ut}}$ & $\begin{array}{c}.08 \\
(.02)\end{array}$ & $\begin{array}{c}.06 \\
(.03)\end{array}$ & $\begin{array}{c}-10 \\
(.03)\end{array}$ & $\begin{array}{l}-.27 \\
(.11)\end{array}$ & $\begin{array}{l}-.15 \\
(.06)\end{array}$ & $\begin{array}{l}-.23 \\
(.12)\end{array}$ & $4^{\text {th }}$ & $\begin{array}{l}-.13 \\
(.05)\end{array}$ & $\begin{array}{l}-.13 \\
(.06)\end{array}$ & $\begin{array}{l}-14 \\
(.05)\end{array}$ & $\begin{array}{l}-15 \\
(.10)\end{array}$ & $\begin{array}{l}-.19 \\
(.06)\end{array}$ & $\begin{array}{l}., 17 \\
(.03)\end{array}$ \\
\hline
\end{tabular}

\section{Correlation between SCS and protein percentage/genetic group/ parity}

Estimates of $R_{g} \& R_{p}$ of $\mathrm{SCS}$ with protein percentage using both data sets are presented in Table 6 . All estimates are moderate and positive values that genetically ranged from .01 to .22 while phenotypically ranged from .04 to .22 and more nearly in agreement with previous works (DE JAGER and KENNEDY, 1987; HARGROVE et 
al., 1981; MAIJALA and HANNA, 1974). Estimates of $L R_{\mathrm{g}}$ that were $>0.15$ was obtained only for high HF\% genes and HF. The lowest estimates of $\mathrm{L} R_{\mathrm{g}}$ were nearer to zero and ranged from .01 to, 03 in different parities for NHB and low $\mathrm{HF} \%$ genes. Increasing estimates of $\mathrm{L} R_{\mathrm{g}}$ were obtained clearly within $2^{\text {nd }}$ and $4^{\text {th }}$ parity with increasing $\mathrm{HF} \%$ genes. STD $R_{\mathrm{g}}$ were lowest than $\mathrm{L} R_{\mathrm{g}}$ within $1^{\text {st }}$ and $2^{\text {nd }}$ parity across different genetic groups. On the other hand, STD $R_{g}$ of NHB and $<25 \%$ HF were superior than the corresponding $\mathrm{L} R_{\mathrm{g}}$. STD $R_{p}$ for HF increased with parity and constitutes another evidence of the preferred and reliable approach than the corresponding $\mathrm{L} R_{\mathrm{g}}$. The lowest $\mathrm{L} R_{\mathrm{p}}$ were presented in the $4^{\text {th }}$ parity for all genetic groups. Generally, negative relationship of SCS with fat and positive one of SCS with protein may suggested that sires that transmit higher SCS can also produce milk, which is lower in fat and higher in protein percentages.

Table 6

Estimates of correlations between SCS and protein \% for all genetic groups in different parities (Korrelationen zwischen SCS und Eiweißgehalt unterschiedlicher genetischer Gruppen und Laktationen)

\begin{tabular}{|c|c|c|c|c|c|c|c|c|c|c|c|c|c|}
\hline \multirow[b]{2}{*}{ 莺 } & \multicolumn{5}{|c|}{ Genetic correlations } & \multirow[b]{2}{*}{ 岸 } & \multicolumn{7}{|c|}{ Phenotypic correlations } \\
\hline & 寽 & $\begin{array}{l}\text { 空 } \\
\text { 总 } \\
\text { ขै }\end{array}$ & 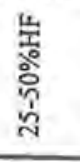 & 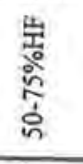 & 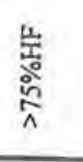 & & 总 & 愛 & 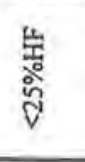 & 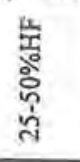 &  & 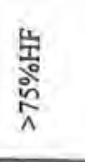 & 㟔 \\
\hline & \multicolumn{13}{|c|}{ Lactation estimates } \\
\hline $1^{31}$ & $\begin{array}{l}.04 \\
(.02)\end{array}$ & $\begin{array}{l}.03 \\
(.02)\end{array}$ & $\begin{array}{l}.12 \\
(.01)\end{array}$ & $\begin{array}{l}15 \\
(.01)\end{array}$ & $\begin{array}{l}.12 \\
(.03)\end{array}$ & $\begin{array}{l}.18 \\
(.03)\end{array}$ & $1^{11}$ & $\begin{array}{l}11 \\
(.02)\end{array}$ & $\begin{array}{l}.10 \\
(.05)\end{array}$ & $\begin{array}{l}.04 \\
(.01)\end{array}$ & $\begin{array}{l}.06 \\
(.09)\end{array}$ & $\begin{array}{l}.05 \\
(.07)\end{array}$ & $\begin{array}{l}.15 \\
(.06)\end{array}$ \\
\hline $2^{\text {nd }}$ & $\begin{array}{l}.04 \\
(.02)\end{array}$ & $\begin{array}{l}.07 \\
(.01)\end{array}$ & $\begin{array}{l}.12 \\
(.01)\end{array}$ & $\begin{array}{l}.17 \\
(.03)\end{array}$ & $\begin{array}{l}15 \\
(.07)\end{array}$ & $\begin{array}{l}.18 \\
(.04)\end{array}$ & $2^{\text {nd }}$ & $\begin{array}{l}.11 \\
(.03)\end{array}$ & $\begin{array}{l}.13 \\
(.06)\end{array}$ & $\begin{array}{l}.08 \\
(.01)\end{array}$ & $\begin{array}{l}.08 \\
(.01)\end{array}$ & $\begin{array}{l}19 \\
(.01)\end{array}$ & $\begin{array}{l}.11 \\
(.09)\end{array}$ \\
\hline $3^{\text {rd }}$ & $\begin{array}{l}.01 \\
(.03)\end{array}$ & $\begin{array}{l}.07 \\
(.02)\end{array}$ & $\begin{array}{l}.13 \\
(.02)\end{array}$ & $\begin{array}{l}.09 \\
(.07)\end{array}$ & $\begin{array}{l}.17 \\
(.08)\end{array}$ & $\begin{array}{l}.22 \\
(.07)\end{array}$ & $3^{\text {nd }}$ & $\begin{array}{l}.08 \\
(.03)\end{array}$ & $\begin{array}{l}.08 \\
(.09)\end{array}$ & $\begin{array}{l}.10 \\
(.03)\end{array}$ & $\begin{array}{l}.12 \\
(.01)\end{array}$ & $\begin{array}{l}.20 \\
(.11)\end{array}$ & $\begin{array}{l}.08 \\
(.10)\end{array}$ \\
\hline \multirow[t]{2}{*}{$4^{\text {th }}$} & $\begin{array}{l}.01 \\
(.03)\end{array}$ & $\begin{array}{l}.04 \\
(.03)\end{array}$ & $\begin{array}{l}.06 \\
(, 04)\end{array}$ & $\begin{array}{l}.06 \\
(.02)\end{array}$ & $\begin{array}{l}.22 \\
(.09)\end{array}$ & $\begin{array}{l}.17 \\
(.03)\end{array}$ & $4^{\text {th }}$ & $\begin{array}{l}.04 \\
(.03)\end{array}$ & $\begin{array}{l}.04 \\
(.08)\end{array}$ & $\begin{array}{l}.04 \\
(.02)\end{array}$ & $\begin{array}{l}.05 \\
(.03)\end{array}$ & $\begin{array}{l}.07 \\
(.03)\end{array}$ & $\begin{array}{l}.06 \\
(.07)\end{array}$ \\
\hline & \multicolumn{13}{|c|}{ Sample test-day estimates } \\
\hline $1^{\text {st }}$ & $\begin{array}{l}.01 \\
(.01)\end{array}$ & $\begin{array}{l}.03 \\
(.02)\end{array}$ & $\begin{array}{l}.09 \\
(.11)\end{array}$ & $\begin{array}{l}.05 \\
(.06)\end{array}$ & $\begin{array}{l}.08 \\
(.09)\end{array}$ & $\begin{array}{l}.08 \\
(.07)\end{array}$ & $1^{11}$ & $\begin{array}{l}.12 \\
(.19)\end{array}$ & $\begin{array}{l}.11 \\
(.04)\end{array}$ & $\begin{array}{l}.04 \\
(.06)\end{array}$ & $\begin{array}{l}.08 \\
(.06)\end{array}$ & $\begin{array}{l}11 \\
(.06)\end{array}$ & $\begin{array}{l}12 \\
(.05)\end{array}$ \\
\hline $2^{\text {nd }}$ & $\begin{array}{l}.03 \\
(.01)\end{array}$ & $\begin{array}{l}.03 \\
(.01)\end{array}$ & $\begin{array}{l}11 \\
(.05)\end{array}$ & $\begin{array}{l}.09 \\
(.03)\end{array}$ & $\begin{array}{l}.20 \\
(.12)\end{array}$ & $\begin{array}{l}.15 \\
(.10)\end{array}$ & $2^{\text {nd }}$ & $\begin{array}{l}13 \\
(.07)\end{array}$ & $\begin{array}{l}10 \\
(.06)\end{array}$ & $\begin{array}{l}.15 \\
(.02)\end{array}$ & $\begin{array}{l}.18 \\
(.08)\end{array}$ & $\begin{array}{l}12 \\
(.08)\end{array}$ & $\begin{array}{l}15 \\
(.03)\end{array}$ \\
\hline $3^{\text {rd }}$ & $\begin{array}{l}.09 \\
(.02)\end{array}$ & $\begin{array}{l}05 \\
(.01)\end{array}$ & $\begin{array}{l}.13 \\
(.06)\end{array}$ & $\begin{array}{l}.12 \\
(.07)\end{array}$ & $\begin{array}{l}19 \\
(.11)\end{array}$ & $\begin{array}{l}.13 \\
(.12)\end{array}$ & $3^{\text {rd }}$ & $\begin{array}{l}.09 \\
(.01)\end{array}$ & $\begin{array}{l}.03 \\
(.07)\end{array}$ & $\begin{array}{l}.17 \\
(.02)\end{array}$ & $\begin{array}{l}.19 \\
(.09)\end{array}$ & $\begin{array}{l}.17 \\
(.09)\end{array}$ & $\begin{array}{l}.19 \\
(.07)\end{array}$ \\
\hline $4^{\text {th }}$ & $\begin{array}{l}11 \\
(.03)\end{array}$ & $\begin{array}{l}.12 \\
(.10)\end{array}$ & $\begin{array}{l}.04 \\
(.01)\end{array}$ & $\begin{array}{l}17 \\
(.09)\end{array}$ & $\begin{array}{l}.09 \\
(.02)\end{array}$ & $\begin{array}{l}.07 \\
(.15)\end{array}$ & $4^{\text {th }}$ & $\begin{array}{l}.02 \\
(.04)\end{array}$ & $\begin{array}{l}.02 \\
(.07)\end{array}$ & $\begin{array}{l}.05 \\
(.02)\end{array}$ & $\begin{array}{l}.07 \\
(.05)\end{array}$ & $\begin{array}{l}19 \\
(.04)\end{array}$ & $\begin{array}{l}.22 \\
(.04)\end{array}$ \\
\hline
\end{tabular}

\section{Correlation between SCS and lactose percentage/genetic group/ parity}

Estimates of $R_{\mathrm{g}}$ and $R_{\mathrm{p}}$ of SCS with lactose percentage using L and STD data sets in different genetic groups across parity are presented in Table 7. In general the relationship of lactose with SCS was negative. The highest $R_{\mathrm{g}}$ of $\mathrm{SCS}_{\mathrm{L}}$ and $\mathrm{Lc}_{\mathrm{L}}$ were $0.32,-0.33,-0.35$ which obtained in the $4^{\text {th }}, 2^{\text {nd }}, 2^{\text {nd }}$ parity for $\mathrm{NHB},<25 \% \mathrm{HF}, 25$ $50 \% \mathrm{HF}$, respectively. These estimates are the highest correlations obtained for the different relationships of SCS with milk production traits. This may indicates that a 
Table 7

Estimates of correlations between SCS and lactose \% for all genetic groups in different parities (Korrelationen zwischen SCS und Laktoseanteil unterschiedlicher genetischer Gruppen und Laktationsnummern)

\begin{tabular}{|c|c|c|c|c|c|c|c|c|c|c|c|c|c|}
\hline \multirow[b]{2}{*}{ हृ } & \multicolumn{5}{|c|}{ Genetic correlations } & & \multicolumn{7}{|c|}{ Phenotypic correlations } \\
\hline & 䍃 & $\begin{array}{l}\text { 岑 } \\
\text { 令 } \\
\text { V }\end{array}$ & 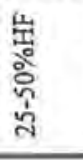 & 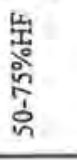 & 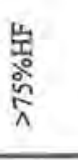 & 空 & 莺 & 严 & 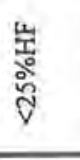 & 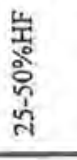 & 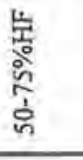 & 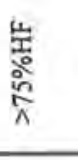 & 㞬 \\
\hline & \multicolumn{13}{|c|}{ Lactational estimates } \\
\hline $1^{11}$ & $\begin{array}{c}.20 \\
(.08)\end{array}$ & $\begin{array}{l}-.32 \\
(.14)\end{array}$ & $\begin{array}{l}-.31 \\
(.10)\end{array}$ & $\begin{array}{l}-.18 \\
(.11)\end{array}$ & $\begin{array}{l}-.11 \\
(.10)\end{array}$ & $\begin{array}{l}-.11 \\
(.17)\end{array}$ & $1^{\text {मी }}$ & $\begin{array}{l}-.13 \\
(.03)\end{array}$ & $\begin{array}{l}-.17 \\
(.10)\end{array}$ & $\begin{array}{l}-.13 \\
(.11)\end{array}$ & $\begin{array}{l}-.22 \\
(.07)\end{array}$ & $\begin{array}{l}-11 \\
(.04)\end{array}$ & $\begin{array}{l}-.01 \\
(.03)\end{array}$ \\
\hline $2^{\text {nd }}$ & $\begin{array}{l}.20 \\
(.07)\end{array}$ & $\begin{array}{l}-.33 \\
(.11)\end{array}$ & $\begin{array}{l}-.35 \\
(.10)\end{array}$ & $\begin{array}{c}-.17 \\
(.07)\end{array}$ & $\begin{array}{l}-.19 \\
(.12)\end{array}$ & $\begin{array}{l}10 \\
(.03)\end{array}$ & $2^{\text {nd }}$ & $\begin{array}{l}-15 \\
(.08)\end{array}$ & $\begin{array}{l}-17 \\
(.09)\end{array}$ & $\begin{array}{l}-.22 \\
(.15)\end{array}$ & $\begin{array}{l}-.22 \\
(.07)\end{array}$ & $\begin{array}{l}-.13 \\
(.07)\end{array}$ & $\begin{array}{l}-.05 \\
(.07)\end{array}$ \\
\hline $3^{\text {id }}$ & $\begin{array}{l}-.28 \\
(11)\end{array}$ & $\begin{array}{l}-21 \\
(.15)\end{array}$ & $\begin{array}{c}-.28 \\
(.08)\end{array}$ & $\begin{array}{l}-23 \\
(.05)\end{array}$ & $\begin{array}{l}-20 \\
(.12)\end{array}$ & $\begin{array}{l}.09 \\
(.07)\end{array}$ & $3^{\text {rd }}$ & $\begin{array}{l}-.19 \\
(.07)\end{array}$ & $\begin{array}{l}-.15 \\
(.08)\end{array}$ & $\begin{array}{l}-.21 \\
(.09)\end{array}$ & $\begin{array}{l}-.18 \\
(.09)\end{array}$ & $\begin{array}{l}.19 \\
(.09)\end{array}$ & $\begin{array}{l}-.11 \\
(01)\end{array}$ \\
\hline \multirow[t]{2}{*}{$4^{\text {th }}$} & $\begin{array}{l}-.32 \\
(.13)\end{array}$ & $\begin{array}{l}-.21 \\
(.10)\end{array}$ & $\begin{array}{l}-.27 \\
(.09)\end{array}$ & $\begin{array}{l}-.25 \\
(.09)\end{array}$ & $\begin{array}{l}-.19 \\
(.12)\end{array}$ & $\begin{array}{l}-.13 \\
(.05)\end{array}$ & $4^{\mathrm{th}}$ & $\begin{array}{l}-.22 \\
(.11)\end{array}$ & $\begin{array}{l}-.15 \\
(.12)\end{array}$ & $\begin{array}{l}.11 \\
(.07)\end{array}$ & $\begin{array}{l}-.17 \\
(.11)\end{array}$ & $\begin{array}{l}-22 \\
(.07)\end{array}$ & $\begin{array}{l}-13 \\
(.07) \\
\end{array}$ \\
\hline & \multicolumn{13}{|c|}{ Sample test-day estimates } \\
\hline $1^{\text {si }}$ & $\begin{array}{c}.07 \\
(.01)\end{array}$ & $\begin{array}{c}.09 \\
(.11)\end{array}$ & $\begin{array}{l}.01 \\
(.12)\end{array}$ & $\begin{array}{l}-.12 \\
(.01)\end{array}$ & $\begin{array}{l}.11 \\
(.01)\end{array}$ & $\begin{array}{l}-10 \\
(.03)\end{array}$ & $1^{\mathrm{H}}$ & $\begin{array}{l}-18 \\
(.10)\end{array}$ & $\begin{array}{l}-.13 \\
(.12)\end{array}$ & $\begin{array}{l}-.11 \\
(.09)\end{array}$ & $\begin{array}{l}-.05 \\
(.09)\end{array}$ & $\begin{array}{l}-.07 \\
(.02)\end{array}$ & $\begin{array}{l}-.09 \\
(.01)\end{array}$ \\
\hline $2^{\text {nd }}$ & $\begin{array}{l}-.07 \\
(.01)\end{array}$ & $\begin{array}{l}-.08 \\
(.03)\end{array}$ & $\begin{array}{l}.03 \\
(, 01)\end{array}$ & $\begin{array}{l}.13 \\
(.01)\end{array}$ & $\begin{array}{l}-.11 \\
(.02)\end{array}$ & $\begin{array}{l}-.18 \\
(.06)\end{array}$ & $2^{\text {nd }}$ & $\begin{array}{l}-.17 \\
(.20)\end{array}$ & $\begin{array}{l}.12 \\
(.12)\end{array}$ & $\begin{array}{l}.08 \\
(.07)\end{array}$ & $\begin{array}{l}.09 \\
(.01)\end{array}$ & $\begin{array}{l}-.07 \\
(.03)\end{array}$ & $\begin{array}{l}-12 \\
(07)\end{array}$ \\
\hline $3^{\text {nd }}$ & $\begin{array}{l}-.09 \\
(.11)\end{array}$ & $\begin{array}{l}-.09 \\
(.02)\end{array}$ & $\begin{array}{l}-07 \\
(.12)\end{array}$ & $\begin{array}{l}-.15 \\
(.02)\end{array}$ & $\begin{array}{l}-.12 \\
(.06)\end{array}$ & $\begin{array}{l}-.22 \\
(.07)\end{array}$ & $3^{\text {rd }}$ & $\begin{array}{l}-19 \\
(.11)\end{array}$ & $\begin{array}{l}-.12 \\
(.09)\end{array}$ & $\begin{array}{l}-.07 \\
(.02)\end{array}$ & $\begin{array}{l}-.11 \\
(.03)\end{array}$ & $\begin{array}{l}-.12 \\
(.09)\end{array}$ & $\begin{array}{l}.18 \\
(.01)\end{array}$ \\
\hline $4^{\text {th }}$ & $\begin{array}{l}-15 \\
(.12)\end{array}$ & $\begin{array}{l}-.11 \\
(.09)\end{array}$ & $\begin{array}{l}-.03 \\
(.03)\end{array}$ & $\begin{array}{l}-.09 \\
(.03)\end{array}$ & $\begin{array}{l}-.08 \\
(.06)\end{array}$ & $\begin{array}{l}.20 \\
(.06)\end{array}$ & $4^{\text {th }}$ & $\begin{array}{l}-22 \\
(.14)\end{array}$ & $\begin{array}{l}-19 \\
(.11)\end{array}$ & $\begin{array}{l}-13 \\
(.02)\end{array}$ & $\begin{array}{l}-.13 \\
(.02)\end{array}$ & $\begin{array}{l}-.15 \\
(.07)\end{array}$ & $\begin{array}{l}.19 \\
(.01)\end{array}$ \\
\hline
\end{tabular}

notable decline in lactose percentage will be occurred under mastitic conditions. $R_{g}$ and $R_{p}$ of $\mathrm{SCS}_{\mathrm{L}}$ with $\mathrm{Lc}_{\mathrm{L}}$ were mostly higher than the corresponding estimates for $\operatorname{SCS}_{L}$ with $P_{L}$ and partially higher than $\operatorname{SCS}_{L}$ with $F_{L}$. These results suggested that correlated responses to single trait selection against SCS ought to be greater for Lc\% than for P\%. Selection only against SCS using the index which involve protein and lactose would decrease expected genetic gain to achieve the breeding goal because there is antagonistic genetic relationship of SCS with both of lactose and protein. Changing estimates of both $R_{\mathrm{B}}$ and $R_{p}$ among different parities in $\mathrm{L}$ data set were greater than the corresponding change in STD especially for HF and crossbred of high HF\%. Phenotypic estimates of STD for NHB generally were higher than that for HF across parities. Change estimates of STD $R_{\mathrm{p}}$ among different genetic groups were more clear in the $1^{\text {st }}$ and $2^{\text {nd }}$ parities than in the $3^{\text {rd }}$ and $4^{\text {th }}$ parities. The lowest $\mathrm{L} R_{\mathrm{p}}$ was -0.01 for HF in the $1^{\text {st }}$ parity, while the lowest STD one was -0.05 obtained for $50-75 \% \mathrm{HF}$ in the $1^{\text {st }}$ parity, Based on these estimates, lactose would not be phenotypically a very reliable indicator of mastitis if used in the $1^{\text {st }}$ parity only for HF and their intermediate crossbreeds. In some genetic groups estimates of correlation between SCS with fat, protein or lactose were near to zero which may reveal that selection for debatable reduction in SCS is accompanied by that the power of selection intensity for these components would be sacrificed.

\section{Acknowledgements}

Special thanks are given to Dr. Gere Tibor, Professor at College of Economics and Agriculture, Gyöngyos, Szent István University, Hungary, for his collaboration 
AFIFI, Y.A.:

\section{References}

The influence of mastitis, milk production and ease of milking on leukocyte counts in the milk. Netherlands Milk and Dairy Journal. 22 (1968), 83-97

BANOS, G.; SHOOK, G.E.;

Genotype by environment interaction and genetic correlations among parities for somatic cell count and milk yield. J. Dairy Sci. 73 (1990), 2563-2573

BOLDMAN, K.G.; KRIESE, L.A.; VAN VLECK, L.D.; VAN TASSELL, C.P.; KACHMAN, S.D.

A Manual for Use of MTDFREML. A set of programs to obtain estimates of variances and covariances U.S. Department of Agric., Agric. Res. Service. 1997

\section{BOOTH, J.M.:}

Progress in the control of mastitis in England and Wales. Veterinary record 122 (1995), 299-302

CHARFEDDINE, N.; ALENDA, R,; GROEN, A.F; M.J. M.J.

Genetic parameters and economic values of lactation somatic cell score and production traits. GIET Workshop on functional traits in cattle health traits. Uppsala, June 8-10 1997

COFFEY, E.M.; VINSON, W.E; PEARSON, R.E.:

Potential of somatic cell concentration in milk as a sire selection criterion to reduce mastitis in dairy cattle. J. Dairy Sci. 69 (1986), 2163-2172

DE JAGER, D; KENNEDY, B.W.:

Genetic parameters of milk yield composition and their relationships with alterantaive breeding goals. $J$. Dairy Sci., 70 (1987), 1258-1264

KENNEDY, B.W.; SETHAR, M.S.; MOXLEY, J.E.; DOWNEY, B.R.:

Heritability of somatic cell count and its relationship with milk yield and composition in Hoisteins. J. Dairy Sci. 65 (1982), 843-851

HARGROVE, G.L.; MBAH, D.A.; ROSENBERGER, J.L.:

Genetic and environmental influences on milk and milk composition production, J. of Dairy Sci., 64 (1981), 1593-1603

MAIJALA, K.; HANNA, M.;

Reliable phenotypic and genetic parameters in dairy cattle. Proc. $1^{\text {st }}$ World Congr. Genet. Appl. Livest. 1 (1974), 54l-454

MODE, R.A.; SWANSON, G.J.T. :

Genetic and statistical properties of somatic cell count and its suitability as an indirect means of reducing the incidence of mastitis in dairy cattle. Animal Breeding Abstract. Vol, 64 (1996) $11,847.857$

MONDARDES, H.G.; HAYES, J.F; MOXLEY, J.E.:

Heritability of lactation cell count measures and their relationships with milk yield and composition in Ayrshire cows. J. Dairy Sci. 67 (1984), 2429-2435

MONARDES, H.G.; HAYES, J,F:

Genetic and phenotypic relationships between lactation cell counts and milk yield and composition of Holstein cows. J. Dairy Sci., 68 (1985), 1250-1257

MONARDES, H.G.; CUE, R.I,; HAYES, J.F.:

Correlations between udder conformation traits and somatic cell count in Canadian Holstein cows. J. Dairy Sci. 73 (1990), 1337-1342

SCHUTZ, M.M; HANSEN, L.B.; STEUERNAGEL, G.R.; RENEAU, J.K.; KUCK, A.L.: Genetic parameters for somatic cells, protein, and fat in milk of Holsteins. J. Dairy Sci, 73 (1990), 494. SO2

WELPER, R.D.; FREEMAN, A.E.:

Genetic parameters for yield traits of Holstein, including lactose and somatic cell score. J. Dairy Sci., 75 (1992), 1342-1348

YOUNG, C.W.; LEGEATES, J.E.; LEECE, J.G.:

Genetic and phenotypic relationship between clinical mastitis, laboratory criteria and udder height. J. Dairy Sci. 43 (1960), 54-62

ZHANG, W.C.; DEKKERS, J.C.M.; BANOS, G.; BURNSIDE, E.B.:

Djustment factors and genetic evaluation for somatic cell score and relationships with other traits of Canadian Holsteins. J. Dairy Sci. 77 (1994), 659-663

Received: 2000-05-09

Acrepted: $2001-02-27$

Authors address

Dr. ASHRAF A. AMIN

Department of Animal Production. Faculty of Agriculture, Suez Canal University, 41522-Ismailia - Egypt

E-Mail: aamin@1 toci.suez.cun.cg. 
Arch. Tierz, Dummerstorf 44 (2001) 3, 276

Buchbesprechung

\section{Praktikum dex Hundeklinik}

HANS G. NIEMAND und PETER F, SUTER

9. Aufl, herausgegeben yon PETER F. SUTER

9. neubearbeitete und erweiterte Auflage, 1346 Seiten, mehr als 458 Abbildungen, davon 83 farbige Abbildungen, 191 Tabellen, Parey Buchverlag Berlin, im Blackwell Wissenschafts-Verlag, 2001

ISBN 3-8263-3154-0, DM 248,00; EUR 126,80; 0 S 1810,00; sFr 218,00

Haustiere, besonders der Hund, sind oft wichtig für das psychische, gesundheitliche und soziale Wohlbefinden von Menschen. So ist es erklärbar, dass der Hund gegenwärtig eine dominierende Stellung in der tierarrztichen Praxis einnimmt. Es ist daher ein bleibendes Verdienst von Hans G. Niemand dieses Standardwerk „Praktikum der Hundeklinik“ vor nunmehr uber dreißig Jahren begrilndet zu haben, das inzwischen von SUTER herausgegeben, bereits in seiner 9. Auflage vorliegt. Getreu dem Grundsatz von Hans G. Niemand, war das aus dem Inund Ausland stammende, renommierte Autorenkollektiv aus Universitaten, Veterinärkliniken und der tierărztlichen Praxis mit seinem Spezialwissen bemuht, bei der Neubearbeitung die Praxisnähe des Buches zu erhalten. Immer rascher zunehmendes Fachwissen fuhrte zur Umarbeitung und Erweiterung der Texte. Weitere, u.a, aus der Behandlungspraxis abzuleitende, Grinde geboten eine Neuaufnahme in einer Reihe von Fragestellungen. So enthált diese Auflage neue Kapitel aber die Euthanasic, dic Bedeutung von Symptomen, Syndromen und abnormen Laborwerten, die Grundsătze des Flussigkeitsersatzes, Schocktherapie und Methoden zur Ernalhrung anorektischer Hunde, Tumorerkrankungen, Alterskrankheiten und Gerontologie. Der allgemeine Buchteil, der acht Kapitel enthălt, umfasst Praxis und Klinik, Futterung und Untersuchung des Hundes, Laberuntersuchungen und Schmerzausschaltung sowie einige der oben genannten neuen Kapitel. Der spezielle, umfangreichste Teil ist den einzelnen Krankheiten gewidmet und beginnt mit Erbkrankheiten, Immunsystemerkrankungen, der Unfall- und Notfallhund und Infektionskrankheiten. Es folgen in 18 Kapiteln die Krankheiten der einzelnen Organsysteme. Den Abschluss bilden Vergiftungen, Tumorerkrankungen und Alterskrankheiten. Jedem Kapitel ist eine umfangreiche Detailgliederung vorangestellt, welche die Arbeit mit diesem Buch oder die Auskunft zu bestimmten Fragestellungen erleichrert. Zu jeder Krankheit werden Ursachen, Pradisposition, Symptome, Diagnose, Therapie und Prognose dargestelit. Wo notwendig, wird auch auf Besonderheiten wie Anamnese. Untersuchungshergang, Differenzialdiagnose, Diagnosesicherung, Notfallmaßnahmen, Komplikationen oder Besonderheiten bei Medikamentdosierungen u.a. hingewiesen. Die knappen, sich auf das Wesentliche beschrankenden, verständlichen und praxisrelevanten, anwendungsorientierten Textfassungen werden durch zahlreiche Abbildungen, schwarz-weiß bzw. farbige Fotographien oder tabellarische Übersichten, wirkungsvoll ergänzl. Am Ende jedes Kapitels findet sich ein Verzeichnis von Spezialliteratur zur jeweiligen Problematik. Ein Anhang des Buches enthält Übersichten zu Referenzbereichen und Umrechungsfaktoren von konventionellen zu S1-Einheiten und div. Umrechnungstabellen z. B, von Gewicht auf Körperoberfläche sowie umfangreiche Verzeichnisse von Dosierungsempfehlungen furr Medikamente und Sachworte.

Mit diesem Buch liegt ein Standardwerk vor, welches hochsten Ansprllchen, sowohl als Nachschlagewerk als auch als tăglicher Ratgeber fur die Praxis, gerecht wird. Es vermittelt in gelungener Kombination unentbehrliches Grundwissen und umfangreiches Spezialwissen. Es ist sowohl als Hilfsmittel fur die Hundepraxis als auch als Lehrbuch fur Studierende unverzichtbar und bedarf keiner besonderen Empfehlung. 